\title{
Kadar Hemoglobin, Jumlah Perdarahan dan Transfusi pada Pasien yang Menjalani Operasi Tumor Otak di Rumah Sakit Umum Pusat Dr. Hasan Sadikin Bandung Tahun 2015-2016
}

\author{
Diana Fitria Ningsih, Suwarman, Tatang Bisri \\ Departemen Anestesiologi dan Terapi Intensif Fakultas Kedokteran Universitas Padjadjaran-RSUP Dr. Hasan \\ Sadikin Bandung
}

\begin{abstract}
Abstrak
Latar Belakang dan Tujuan: Operasi tumor otak berhubungan erat dengan risiko perdarahan dalam jumlah besar dan menyebabkan anemia. Efek klinis anemia dapat diperbaiki dengan pemberian transfusi darah. Transfusi diberikan dengan target level Hemoglobin ( $\mathrm{Hb}$ ) antara 9 sampai $10 \mathrm{gr} / \mathrm{dL}$. Tujuan penelitian ini adalah untuk mengetahui gambarankadarHb,jumlah perdarahan serta pemberian transfusi darah pada pasien yang menjalanioperasi tumorotak. Subjek dan Metode: Penelitian observasional yang dilakukan secara retrospektif terhadap 126 objek penelitian yang diambil dari rekam medis.

Hasil: Kadar $\mathrm{Hb}$ prabedah rata-rata sebesar 13,23 $\pm 1,35 \mathrm{gr} / \mathrm{dL}$. Kadar Hb pascabedah $<9$ gr/dL sebanyak 15 pasien, $\mathrm{Hb}$ 9-10 gr/dL sebanyak 6 pasien dan $\mathrm{Hb}>10 \mathrm{gr} / \mathrm{dL}$ sebanyak 105 pasien. Jumlah perdarahan rata-rata sebesar $1159 \pm 1032,66 \mathrm{cc}$. Jumlah rata-rata transfusi yang diterima tiap pasien terdiri atas PRC $365,81 \pm 258,70 \mathrm{cc}$, FFP $425,45 \pm 274,78 \mathrm{cc}$ dan satu pasien mendapat WB $250 \mathrm{cc}$. Terdapat hubungan antara perdarahan dengan jenis tumor dan jenis operasi $(\mathrm{p}<0,05)$. Terdapat hubungan antara kadar $\mathrm{Hb}$ pascabedah dengan perdarahan dan $\operatorname{tranfusi}(\mathrm{p}<0,05)$. Simpulan: Tidak ditemukan pasien dengan anemia berat sebelum operasi. Pemberian transfusi pada pasien yang menjalani operasi tumor otak masih berlebihan. Jumlah perdarahan berhubungan dengan jenis tumor dan jenis operasi. Kadar $\mathrm{Hb}$ pascabedah lebih ditentukan oleh perdarahan daripada transfusi.
\end{abstract}

Kata kunci: Hemoglobin, operasi tumor otak, perdarahan, transfusi

JNI 2018;7 (2): 71-9

\section{Hemoglobin Levels, Blood Loss and Transfusion in Patients Underwent Brain Tumor Surgery at Dr. Hasan Sadikin Bandung General Hospital During 2015-2016}

\begin{abstract}
Background and Objective: Brain tumor surgery is closely related to the risk of numerous bleeding that can cause the patient to be in an anemic condition. The clinical effects of anemia can be improved by administered blood transfusions. Transfusion can beadministered with targetHemoglobin $(\mathrm{Hb})$ level between 9 to $10 \mathrm{gr} / \mathrm{dL}$. The purpose of this study was to describe levels of $\mathrm{Hb}$, blood loss and how blood transfusion administered in patients undergoing brain tumor surgery. Subject and Method: Observational study with retrospective approach to 126 objects taken from medical records. Result: The average of preoperative $\mathrm{Hb}$ level was 13,23 $\pm 1,350 \mathrm{gr} / \mathrm{dL}$. Number of patients with postoperative $\mathrm{Hb}$ level $<9 \mathrm{gr} / \mathrm{dL}$ were 15 patients, $\mathrm{Hb} 9-10 \mathrm{gr} / \mathrm{dL}$ were 6 patients and $\mathrm{Hb}>10 \mathrm{gr} / \mathrm{dL}$ were 105 patients. The rate of blood loss was $1159 \pm 1032,66 \mathrm{cc}$. Average amount of transfusion received by each patients were PRC $365,81 \pm 258,70 \mathrm{cc}$, FFP $425,45 \pm 274,78 \mathrm{cc}$ and one patient received WB $250 \mathrm{cc}$. There was a relationship between blood loss with tumor type and type of surgery $(\mathrm{p}<0,05)$. There was a relationship between postoperative Hb level with blood loss and transfusion $(\mathrm{p}<0,05)$.

Conclusion: No patients with severe preoperative anemia were found in this study. Transfusion administration of brain tumor surgery is still excessive. The rate of blood loss was associated with the type of tumor and surgical access. Postoperative $\mathrm{Hb}$ level is more determined by blood loss than tranfusion.
\end{abstract}

Key words: Hemoglobin, brain tumor surgery, blood loss, transfusions.

JNI 2018;7 (2): 71-9 


\section{Pendahuluan}

Operasi bedah saraf umumnya berhubungan dengan kehilangan darah dalam jumlah besar dan cepat. Pasien dapat berada pada kondisi anemia intrabedah dan tidak stabil yang akhirnya dapat mengakibatkan morbiditas serius bahkan mortalitas. ${ }^{1}$ Kebutuhan transfusi untuk memperbaiki kondisi anemia ini bergantung pada usia, jenis tumor dan teknik pembedahan. ${ }^{2,3}$ Oksigen harus diangkut secara efektif dari atmosfer ke jaringan guna mempertahankan metabolisme normal. ${ }^{4}$ Hemoglobin $(\mathrm{Hb})$ adalah pengangkut utama dari oksigen dalam pemenuhan kebutuhan jaringan (oxygen transport). $\mathrm{Hb}$ memiliki kemampuan untuk melepaskan lebih banyak oksigen saat pasokan tidak memadai atau kebutuhan seluler meningkat. ${ }^{5}$ Anemia didefinisikan sebagai suatu kondisi tubuh dengan penurunan jumlah sel darah merah yang beredar. ${ }^{6,7}$ Anemia merupakan salah satu faktor penyebab cedera sekunder pada otak. ${ }^{89}$ Bila terjadi anemia yang dapat membahayakan jiwa maka diperlukan transfusi darah ataupun produk darah untuk mempertahankan konsentrasi $\mathrm{Hb}$ atau hematokrit $(\mathrm{Ht}) .{ }^{10}$

Transfusi sendiri telah dikaitkan dengan peningkatan kejadian infeksi, multiple organ failure (MOF) termasuk gagal napas, peningkatan kejadian tromboembolik dan kematian. ${ }^{8}$ Tidak ada aturan baku tentang saat harus dilakukan transfusi. Pasien dengan $\mathrm{Ht}$ normal umumnya akan mendapat transfusi setelah kehilangan darah lebih besar dari 10-20\% dari volume darah mereka. Transfusi tidak direkomendasikan sampai $\mathrm{Ht}$ turun menjadi $24 \%$ atau lebih rendah $(\mathrm{Hb}<8 \mathrm{gr} / \mathrm{dL})$, namun perlu diperhitungkan tingkat kehilangan darah dan kondisi komorbid pasien. ${ }^{10}$ Penggunaan transfusi yang bebas dengan sasaran mempertahankan konsentrasi $\mathrm{Hb}$ yang asal-asalan, bukan saja tidak efektif dalam memperbaiki luaran, tapi juga kemungkinan membahayakan. Pasokan oksigen adalah faktor penting pada cedera otak sekunder, klinisi memberikan target level $\mathrm{Hb}$ minimum antara 9 sampai $10 \mathrm{gr} / \mathrm{dL} .^{8,11}$

Tujuan penelitian ini adalah untuk mengetahui gambaran kadar $\mathrm{Hb}$ dan $\mathrm{Ht}$ prabedah dan pascabedah, jumlah perdarahan dan pemberian tranfusi pada pasien yang menjalani operasi tumor otak di RSUP Dr. Hasan Sadikin Bandung periode Juni 2015 sampai dengan Juni 2016.

\section{Subjek dan Metode}

Penelitian ini merupakan penelitian deskriptif observasional yang dilakukan secara retrospektif mengenai gambaran kadar $\mathrm{Hb}$ dan $\mathrm{Ht}$ prabedah dan pascabedah, jumlah perdarahan dan pemberian tranfusi pada pasien yang menjalani operasi tumor otak di Rumah Sakit Dr. Hasan Sadikin (RSHS) Bandung periode Juni 2015 sampai Juni 2016. Subjek penelitian ini adalah rekam medis pasien yang menjalani operasi tumor otak di Rumah Sakit Dr. Hasan Sadikin Bandung yang memenuhi kriteria inklusi dan tidak termasuk kriteria eksklusi. Kriteria inklusi pada penelitian ini adalah pasien yang menjalani operasi tumor otak di RSUP Dr. Hasan Sadikin Bandung periode Juni 2015 sampai Juni 2016 yang berusia 18 sampai 60 tahun. Kriteria eksklusi pada penelitian ini adalah rekam medis pasien tidak lengkap.

Pengumpulan data secara keseluruhan dilakukan sejak disetujui oleh Komite Etik Penelitian Kesehatan Fakultas Kedokteran Universitas Padjadjaran/RSHS pada bulan Desember 2016 menggunakan data rekam medis pasien yang menjalani operasi tumor otak pada periode Juni 2015 sampai dengan Juni 2016. Data yang diambil adalah usia, jenis kelamin, jenis tumor otak, kadar $\mathrm{Hb}$ dan $\mathrm{Ht}$ prabedah dan pascabedah, jumlah perdarahan dan jumlah transfusi dan cairan. Data kategorik dideskripsikan dengan distribusi frekuensi dan proporsi. Sedangkan untuk data numerik sepertia usia dideskripsikan dalam bentuk ukuran pemusatan dan penyebaran data numerik.

Analisis data digunakan untuk mengetahui karakteristik pasien yang menjalani operasi tumor otak. Deskripsi karakteristik dan status pasien ditampilkan dalam bentuk tabel. Data kategorik dideskripsikan dengan jumlah (n) dan persentase (\%). Data numerik dideskripsikan 
dalam bentuk rata-rata, standar deviasi (SD), median, dan rentang (minimal-maksimal). Untuk data kategorik nilai $\mathrm{p}$ dihitung berdasarkan uji Chi Square dengan alternatif uji Exact Fisher/ Kolmogorov Smirnov dan Exact Fisher apabila syarat dari Chi Square tidak terpenuhi. Nilai kemaknaan berdasarkan nilai $p<0,05$. Nilai $\mathrm{p}<0,05$ artinya signifkan atau bermakna secara statistik.

\section{Hasil}

Total terdapat 126 pasien yang dioperasi selama

Tabel 1. Karakteristik Umum

\begin{tabular}{ll}
\hline Variabel & $\mathrm{n}=126$ \\
\hline Usia (tahun) & \\
Mean \pm SD & $42,16 \pm 9,23$ \\
Median & 43,00 \\
Range (min-max) & $18,00-60,00$ \\
Jenis kelamin, n (\%) & \\
Laki-laki & $26(20,6)$ \\
Perempuan & $100(79,4)$ \\
Jumlah pasien, n (\%) & \\
Mendapat transfusi & $56(44,8)$ \\
Tidak Mendapat Transfusi & $70(55,6)$ \\
Hemoglobin prabedah (gr/dL) & \\
Mean \pm SD & $13,23 \pm 1,35$ \\
Median & 13,40 \\
Range (min-max) & $9,80-16,40$ \\
Hematokrit prabedah (\%) & \\
Mean \pm SD & $39,19 \pm 3,54$ \\
Median & 40,00 \\
Range (min-max) & $29,00-47,00$ \\
Hematokrit pascabedah (\%) & \\
Mean \pm SD & $34,03 \pm 6,03$ \\
Median & 35,00 \\
Range (min-max) & $15,00-49,00$ \\
Jumlah perdarahan (cc) & \\
Mean \pm SD & $1159 \pm 1032,66$ \\
Median & 900,00 \\
Range (min-max) & \\
\hline & \\
\hline
\end{tabular}

Tabel 2. Jenis Tumor $(n=126)$

\begin{tabular}{|c|c|}
\hline \multicolumn{2}{|l|}{ Jenis tumor $(\mathrm{n}, \%)$} \\
\hline \multicolumn{2}{|l|}{ Meningioma } \\
\hline Astrocytoma & $87(69,0 \%)$ \\
\hline Makroadenoma & $6(4,8 \%)$ \\
\hline Glioma & $4(3,2 \%)$ \\
\hline Oligodendroglioma & $4(3,2 \%)$ \\
\hline Cranipharyngioma & $3(2,4 \%)$ \\
\hline Schwannoma & $3(2,4 \%)$ \\
\hline Metastasis Carcinoma & $3(2,4 \%)$ \\
\hline Osteoma & $2(1,6 \%)$ \\
\hline Rhabdomyosarcoma & $2(1,6 \%)$ \\
\hline Kista & $2(1,6 \%)$ \\
\hline Neurofibroma & $1(0,8 \%)$ \\
\hline Papilloma & $1(0,8 \%)$ \\
\hline Hemangiopericytoma & $1(0,8 \%)$ \\
\hline Osseous Plaques & $1(0,8 \%)$ \\
\hline \multicolumn{2}{|c|}{$\begin{array}{l}\text { Keterangan: data kategorik disajikan dengan jumlah } \\
\text { frekuensi dan persentase sedangkan data numerik } \\
\text { disajikan dengan rata-rata, standar deviasi dan range. }\end{array}$} \\
\hline $\begin{array}{l}\text { Tabel 3. Gambaran } \\
\text { Prabedah }\end{array}$ & Kelompok Hematokrit \\
\hline Variabel & $\mathrm{n}(\%)$ \\
\hline \multicolumn{2}{|l|}{ Hematokrit prabedah (\%) } \\
\hline $30-<38$ & $32(25,3)$ \\
\hline $26-<30$ & $1(0,7)$ \\
\hline$<26$ & - \\
\hline
\end{tabular}

Keterangan: data kategorik disajikan dengan jumlah/ frekuensi dan persentase

penelitian ini. Pasien yang diteliti memiliki usia antara 18-60 tahun dengan rata-rata usia sebesar $42,16 \pm 9,23$ tahun. Jenis kelamin pasien sebagian besar adalah perempuan sebanyak 100 pasien $(79,4 \%)$. Jumlah pasien yang mendapat transfusi sebanyak 56 pasien $(44,8 \%)$. Hb prabedah ratarata sebesar 13,23 $\pm 1,35 \mathrm{gr} / \mathrm{dL}$, Ht prabedah ratarata sebesar $39,19 \pm 3,54 \%$ dan $\mathrm{Ht}$ pascabedah rata-rata sebesar $34,03 \pm 6,03 \%$. Jenis tumor paling banyak adalah meningioma yaitu 87 pasien (69\%). Jumlah perdarahan selama operasi mempunyai median sebesar 900cc dengan rentang antara 10-8000cc (Tabel 1).

Anemia dibagi menjadi tiga kategori, yaitu severe 
Tabel 4. Gambaran Transfusi dan Jenis Tumor yang Mendapat Transfusi

\begin{tabular}{ll}
\hline Variabel & $\mathrm{n}=56$ \\
\hline Packed red cell (cc) & $365,81 \pm 258,70$ \\
Mean \pm SD & 220,00 \\
Median & $150,00-1490,00$ \\
Range (min-max) & \\
Fresh frozen plasma (cc) & $425,45 \pm 274,78$ \\
Mean \pm SD & 400,00 \\
Median & $150,00-1140,00$ \\
Range (min-max) & 250,00 \\
Whole blood (cc) & \\
Jenis tumor yang mendapat & \\
transfusi, $\mathrm{n}(\%)$ & $49(87,5)$ \\
Meningioma & $2(3,57)$ \\
Rhabdomyosarcoma & $1(1,78)$ \\
Glioma & $1(1,78)$ \\
Metastatic Carcinoma & $1(1,78)$ \\
Schwannoma & $1(1,78)$ \\
Oligodendroglioma & $1(1,78)$ \\
Neurofibroma &
\end{tabular}

Keterangan: data kategorik disajikan dengan jumlah/ frekuensi dan persentase sedangkan data numerik disajikan dengan rata-rata, standar deviasi dan range.

( $\mathrm{Ht}<26 \%)$, moderate (Ht 26\% sampai $<30 \%$ ) dan mild (Ht 30\% sampai <38\%). Tidak ditemukan pasien dengan anemia berat pada penelitian ini (Tabel 2). Jumlah pasien yang mendapat tranfusi selama operasi sebanyak 56 pasien. Pemberian tranfusi PRC rata-rata sebesar $365,81 \pm 258,70 \mathrm{cc}$, FFP rata-rata sebesar $425,45 \pm 274,78 \mathrm{cc}$ sedangkan untuk transfusi whole blood (WB) hanya diberikan pada satu pasien yaitu sebanyak 250cc. Terdapat tujuh jenis tumor otak yang teridentifikasi pada 56 pasien yang mendapat transfusi. Jenis tumor otak paling banyak yang mendapat transfusi yaitu meningioma sebanyak 49 pasien $(87,5 \%$; Tabel 3$)$.

Jumlah perdarahan terbanyak terdapat pada kelompok $\mathrm{Hb}<9 \mathrm{gr} / \mathrm{dL}$ dengan median sebesar 2500 cc dan rentang antara 1200-8000cc. Pemberian transfusi maupun cairan paling banyak diberikan pada kelompok $\mathrm{Hb}$ pascabedah $<9 \mathrm{gr} /$ dL yaitu PRC dengan median sebesar 600cc dan rentang antara 190-1490cc, FFP dengan median 280cc dan rentang 0-1140cc, kristaloid dengan median 4000cc dan rentang antara 500-6000cc, koloid dengan median $1500 \mathrm{cc}$ dan rentang antara 500-6000cc. Transfusi WB hanya diberikan pada kelompok $\mathrm{Hb}$ pascabedah $>10 \mathrm{gr} / \mathrm{dL}$ Kadar $\mathrm{Ht}$ saat mulai transfusi intrabedah tertinggi terdapat pada kelompok $\mathrm{Hb}$ pascabedah $>10$ $\mathrm{gr} / \mathrm{dL}$ yaitu rata-rata pada $\mathrm{Ht} 29,65 \pm 4,90 \%$ (Tabel 4). Perdarahan terbanyak berasal dari tumor ekstrinsik dan pada pasien dengan tindakan operasi craniotomy tumor removal. Hasil uji statistik diperoleh informasi nilai P pada variabel jenis tumor otak dan jenis operasi lebih kecil dari 0,05 (nilai $\mathrm{P}<0,05$ ) yang berarti bermakna secara statistik dengan demikian dapat dijelaskan bahwa terdapat perbedaan persentase yang signifikan secara statistik antara variabel jenis tumor otak dan jenis operasi pada kelompok perdarahan $\leq 1000$ cc dan perdarahan $>1000$ cc (Tabel 5).

$\mathrm{Hb}$ pascabedah dikelompokkan menjadi tiga kelompok. Sebagian besar pasien mempunyai $\mathrm{Hb}$ pascabedah $>10 \mathrm{gr} / \mathrm{dL}$. Hasil uji statistik pada kelompok penelitian diperoleh nilai p pada variabel perdarahan dan transfusi lebih kecil dari 0,05 (nilai $p<0,05$ ) yang berarti bermakna secara statistik dengan demikian dapat dijelaskan bahwa terdapat perbedaan persentase yang signifikan secara statistik antara variabel perdarahan dan transfusi pada kelompok $\mathrm{Hb}$ pascabedah $<9 \mathrm{gr} /$ $\mathrm{dL}, 9-10 \mathrm{gr} / \mathrm{dL}$ dan $>10 \mathrm{gr} / \mathrm{dL}$ (Tabel 6).

\section{Pembahasan}

Perdarahan yang terjadi pada operasi bedah saraf pada umumnya besar dan dapat berlangsung cepat. Pasien dapat berada pada kondisi anemia intrabedah maupun pascabedah sehingga memerlukan transfusi darah atau produk darah dengan volume besar pula. Pemberian transfusi untuk mempertahankan kadar $\mathrm{Hb}$ dalam darah harus sesuai indikasi, tidak boleh kurang atau berlebih. Dari penelitian ini didapatkan pasien dengan anemia prabedah ringan sebanyak $25,3 \%$ dan anemia prabedah sedang sebanyak $0,7 \%$. Tidak didapatkan pasien dengan anemia berat. Hal ini sedikit berbeda dengan hasil penelitian di Ohio yang menyebutkan bahwa pada 6576 pasien 
Tabel 5. Gambaran Kelompok Hb Pascabedah pada Pasien yang Mendapat Transfusi Berdasarkan Kadar Hb dan Ht saat Mulai Transfusi, Jumlah Perdarahan, Transfusi dan Cairan

\begin{tabular}{|c|c|c|}
\hline \multirow[t]{3}{*}{ Variabel } & \multicolumn{2}{|c|}{ Kadar Hemoglobin Pascabedah (gr/dL) } \\
\hline & $<<$ & $9-10$ \\
\hline & $\mathrm{n}=13$ & $\mathrm{n}=3$ \\
\hline \multicolumn{3}{|l|}{ Perdarahan (cc) } \\
\hline Mean \pm SD & $2915,38 \pm 1695,99$ & $2833,33 \pm 763,76$ \\
\hline Median & 2500,00 & 3000,00 \\
\hline Range (min-max) & $1200,00-8000,00$ & $2000,00-3500,00$ \\
\hline \multicolumn{3}{|c|}{ Kadar Hb saa awal transfusi (gr/dL) } \\
\hline Mean \pm SD & $8,30 \pm 2,28$ & $7,53 \pm 0,66$ \\
\hline Median & 8,90 & 7,70 \\
\hline Range (min-max) & $4,20-11,50$ & $6,80-8,10$ \\
\hline \multicolumn{3}{|c|}{ Kadar Ht saat awal transfusi (\%) } \\
\hline Mean \pm SD & $26,53 \pm 6,00$ & $26,00 \pm 1,00$ \\
\hline Median & 27,00 & 26,00 \\
\hline Range (min-max) & $16,00-36,00$ & $25,00-27,00$ \\
\hline \multicolumn{3}{|l|}{ Transfusi PRC (cc) } \\
\hline Mean $\pm \mathrm{SD}$ & $642,30 \pm 341,03$ & $493,33 \pm 215,71$ \\
\hline Median & 600,00 & 400,00 \\
\hline Range (min-max) & $190,00-1490,00$ & $340,00-740,00$ \\
\hline \multicolumn{3}{|l|}{ Transfusi FFP (cc) } \\
\hline Mean $\pm \mathrm{SD}$ & $283,84 \pm 343,06$ & $93,33 \pm 161,65$ \\
\hline Median & 280,00 & 0,00 \\
\hline Range (min-max) & $0,00-1140,00$ & $0,00-280,00$ \\
\hline Transfusi WB (cc) & - & - \\
\hline \multicolumn{3}{|l|}{ Cairan kristaloid } \\
\hline Mean $\pm \mathrm{SD}$ & $3769,23 \pm 1423,25$ & $3333,33 \pm 763,76$ \\
\hline Median & 4000,00 & 3500,00 \\
\hline Range (min-max) & $500,00-6000,00$ & - \\
\hline Cairan koloid (cc) & & \\
\hline Mean $\pm \mathrm{SD}$ & $1846,15 \pm 1344,50$ & - \\
\hline Median & 1500,00 & - \\
\hline Range (min-max) & $500,006000,00$ & - \\
\hline
\end{tabular}

Keterangan: data numerik disajikan dengan rata-rata, standar deviasi dan range

yang menjalani operasi bedah kepala elektif, didapatkan $2,7 \%$ pasien dengan anemia prabedah sedang-berat dan $28,4 \%$ dengan anemia prabedah ringan. ${ }^{7}$ Penelitan lain di Ohio tahun 2015 menyebutkan juga bahwa dari 668 pasien yang menjalani operasi aneurisma kepala didapatkan $30 \%$ pasien dengan anemia prabedah. ${ }^{13}$ Hal ini dapat disebabkan operasi yang dijalani adalah operasi elektif sehingga masih cukup waktu dilakukan perbaikan kondisi anemia sebelum operasi. Terdapat peningkatan angka kematian pada pasien dengan tingkat $\mathrm{Hb}<7 \mathrm{gr} / \mathrm{dL}$ sebelum operasi. ${ }^{6}$ Pada penelitian ini tidak didapatkan pasien yang mempunyai $\mathrm{Hb}<7 \mathrm{gr} / \mathrm{dL}$ sebelum operasi. Penelitan di Ohio tahun 2015 juga menyebutkan bahwa $28 \%$ pasien dari $30 \%$ pasien 
Tabel 6. Hubungan antara Tumor Otak dan Jenis Operasi pada Kelompok Perdarahan $\leq 1000 \mathrm{cc}$ dan Perdarahan $>1000 c c$

\begin{tabular}{|c|c|c|c|}
\hline \multirow[t]{3}{*}{ Variabel } & Perdarahan (cc) & & \\
\hline & $\leq 1000$ & $>1000$ & Nilai P \\
\hline & $\mathrm{n}=78$ & $\mathrm{n}=48$ & \\
\hline Tumor otak (n,\%) & & & $0,011 * *$ \\
\hline Intrinsik & $16(20,5$ & $2(4,2)$ & \\
\hline Ekstrinsik & $62(79,5)$ & $46(95,8)$ & \\
\hline Jenis operasi $(n, \%)$ & & & $0,024 * *$ \\
\hline Transphenoid tumor removal & $8(10,3)$ & $0(0,0)$ & \\
\hline Craniotomy tumor removal & $70(89,7)$ & $48(100,0)$ & \\
\hline
\end{tabular}

Keterangan: data kategorik nilai $\mathrm{p}$ dihitung berdasarkan uji Chi-Square dengan alternatif uji Exact Fisher/ Kolmogorov Smirnov dan Exact Fisher apabila syarat dari Chi-Square tidak terpenuhi. Nilai kemaknaan berdasarkan nilai $\mathrm{p}<0,05$. Tanda* menunjukkan nilai $\mathrm{p}<0,05$ artinya signifkan atau bermakna secara statistik.

Tabel 7. Hubungan antara Perdarahan dan Transfusi pada Kelompok Kadar Hb Pascabedah $<9 \mathrm{gr} / \mathrm{dl}, 9-10 \mathrm{gr} / \mathrm{dl}$ dan $>10 \mathrm{gr} / \mathrm{dl}$

\begin{tabular}{lcccc}
\hline Variabel & \multicolumn{3}{c}{ Kadar Hemoglobin Pascabedah $(\mathrm{gr} / \mathrm{dL})$} & \\
& $<9$ & $9-10$ & $\mathrm{n}=10$ & Nilai P \\
& $\mathrm{n}=15$ & $\mathrm{n}=6$ & & $0,000^{* *}$ \\
Perdarahan (n, \%) & & & & \\
$\leq 1000 \mathrm{cc}$ & $2(13,3)$ & $2(33,3)$ & $74(70,5)$ & $0,002^{* *}$ \\
$>1000 \mathrm{cc}$ & $13(86,7)$ & $4(66,7)$ & $31(29,5)$ & \\
Jumlah pasien (n, \%) & & & & \\
Mendapat transfusi & $13(86,7)$ & $3(50,0)$ & $40(38,1)$ & $65(61,9)$ \\
Tidak mendapat transfusi & $2(13,3)$ & $3(50,0)$ & & \\
\hline
\end{tabular}

Keterangan: data kategorik nilai p dihitung berdasarkan uji Chi-Square dengan alternatif uji Exact Fisher/ Kolmogorov Smirnov dan Exact Fisher apabila syarat dari Chi-Square tidak terpenuhi. Nilai kemaknaan berdasarkan nilai $\mathrm{p}<0,05$. Tanda* menunjukkan nilai $\mathrm{p}<0,05$ artinya signifkan atau bermakna secara statistik.

yang menjalani operasi aneurisma dengan anemia prabedah mendapatkan transfusi perioperatif. ${ }^{13}$ Pada penelitian ini didapatkan jumlah perdarahan pada keseluruhan operasi berkisar antara 10$8000 \mathrm{cc}$. Terdapat hubungan yang bermakna secara statistik antara jumlah perdarahan dengan jenis tumor dan jenis operasi $(p<0,05)$. Diantara jenis tumor dan jenis operasi, yang paling berhubungan dengan perdarahan adalah jenis tumor otak terutama tumor ekstrinsik. Tumor ekstrinsik yang paling banyak ditemukan pada penelitian ini adalah meningioma yaitu 87 pasien $(69 \%)$. Permasalahan utama saat eksisi meningioma intrakranial adalah perdarahan dan prosedur operasi yang dapat memanjang karena meningioma mempunyai vaskularisasi yang tinggi dan ditambah dengan penanganan hemostasis yang terkadang sangat sulit. ${ }^{12}$ Prosedur operasi yang paling mempengaruhi perdarahan adalah craniotomy tumor removal. Perdarahan paling sedikit yang ditemukan pada penelitian ini berjumlah $10 \mathrm{cc}$, berasal dari operasi transphenoid tumor removal. Hal ini membuktikan bahwa kemajuan dalam teknik operasi bedah saraf seperti penggunaan teknik microsurgical secara signifikan membantu mengurangi perdarahan sekaligus kebutuhan transfusi intraoperatif.

Penelitian ini mendapatkan hasil pasien yang mendapat transfusi sebanyak 44,8\% dari 126 pasien yang menjalani operasi tumor kepala, dengan rata-rata pemberian PRC sebesar $365,81 \pm 258,70 \mathrm{cc}$, FFP sebesar $425,45 \pm 274,78 \mathrm{cc}$ dan terdapat satu pasien yang mendapat WB 
sebanyak $250 \mathrm{cc}$. Hal ini tidak sesuai dengan hasil penelitian yang dilakukan di Jerman menyebutkan bahwa hanya $1,4 \%$ dari 718 pasien yang menjalani operasi tumor kepala membutuhkan transfusi darah. Beberapa strategi baru yang telah terbukti efektif mengurangi transfusi perioperatif produk darah yang dapat diimplementasikan seperti tranfusi secara restriktif, hemodilusi normovolemik akut dan autotranfusi. ${ }^{14}$

Banyaknya kebutuhan transfusi tergantung pada usia, jenis tumor dan teknik pembedahan. Low grade glioma, reseksi transsphenoidal tumor hipofisis atau astrocytoma biasanya tidak memerlukan transfusi darah. Kebutuhan transfusi dapat meningkat pada bayi dan tumor dengan vaskularisasi yang tinggi seperti pada meningioma dan tumor cerebellopontine., ${ }^{2,3}$ Dari penelitian ini juga didapatkan satu pasien yang menjalani operasi transphenoid tumor removal mendapat transfusi PRC 200 cc dengan perdarahan $700 \mathrm{cc}$ dan $\mathrm{Hb}$ pascabedah sebesar 11,1 gr/dL. Jenis tumor otak paling banyak yang mendapat transfusi adalah meningioma yaitu sebanyak 49 pasien $(87,5 \%)$. Penggunaan transfusi yang bebas dengan sasaran mempertahankan konsentrasi $\mathrm{Hb}$ yang asal-asalan $(10 \mathrm{gr} / \mathrm{dl})$ bukan saja tidak efektif dalam memperbaiki luaran, tapi juga kemungkinan membahayakan. ${ }^{8,11}$ Keputusan pemberian transfusi sebagian besar dinilai secara subjektif oleh dokter anestesi (residen/ PPDS) dengan panduan perhitungan perdarahan, kadar perkiraan $\mathrm{Hb}$ intrabedah yang dihitung secara manual, trend hemodinamik arteri atau central venous pressure (bila dipasang) yang memungkinkan terjadinya transfusi yang tidak tepat (overtranfuse/undertransfuse). Salah satu tugas anestesi yang paling penting dan sulit adalah memonitor dan memperkirakan perdarahan. Meskipun perkiraan diperumit oleh pendarahan yang tersembunyi dalam luka atau di bawah surgical drapes, ketepatan perhitungan sangatlah penting untuk memandu pemberian terapi cairan dan transfusi. Metode yang paling umum digunakan untuk memperkirakan perdarahan adalah dengan pengukuran darah pada wadah hisap dan perkiraan perdarahan secara visual pada spons bedah. Operasi yang dilakukan sebagian besar dikerjakan oleh operator yang sedang belajar (residen) yang dapat membuat perdarahan lebih banyak serta waktu operasi yang lebih panjang dibanding dengan operator yang sudah berpengalaman (konsulen). Namun hal ini memerlukan penelitian lebih lanjut.

Idealnya, kehilangan darah harus diganti dengan kristaloid atau larutan koloid untuk menjaga volume intravaskular (normovolemia) sampai pada titik dimana pasien harus menerima transfusi. Klinisi memberikan larutan Ringer laktat atau plasmalyte kira-kira tiga sampai empat kali volume darah yang hilang atau koloid dalam rasio 1:1.10 Dari penelitian ini didapatkan bahwa pemberian cairan selama operasi pada kelompok $\mathrm{Hb}$ pascabedah $<9 \mathrm{gr} / \mathrm{dL}$ memiliki rata-rata yang lebih besar daripada kelompok $\mathrm{Hb}$ pascabedah lainnya dengan perkiraan rasio 1:4. $\mathrm{Hb}$ pascabedah $<9 \mathrm{gr} / \mathrm{dL}$ ini dapat disebabkan oleh pemberian tranfusi belum mencukupi atau karena proses hemodilusi, diperlukan penelitian lebih lanjut untuk dapat membuktikannya.

Pasokan oksigen adalah faktor penting pada cedera otak sekunder, oleh karena itu banyak klinisi yang memberikan target level $\mathrm{Hb}$ antara 9 sampai $10 \mathrm{gr} / \mathrm{dL}^{8,11}$ Penelitian di Canada menyebutkan bahwa $\mathrm{Hb}>9$ gr/dL berhubungan dengan peningkatan luaran fungsi neurologik dalam 6 bulan. ${ }^{18}$ Studi mikrodialysis yang dilakukan di Pennsylvania menyebutkan bahwa konsentrasi $\mathrm{Hb}<9$ gr/dL berhubungan dengan peningkatan kejadian hipoksia otak dan disfungsi energi sel pada pasien dengan SAH. ${ }^{19}$ Penelitian di Canada menyebutkan bahwa rata-rata $\mathrm{Hb}$ $<9$ gr/dL dalam 7 hari berhubungan dengan peningkatan tiga kali lipat kejadian mortalitas pada pasien dengan cedera kepala berat di ICU. ${ }^{20}$ Penelitian lain yang dilakukan di Texas terhadap 200 pasien dengan trauma kepala menyebutkan bahwa mempertahankan konsentrasi $\mathrm{Hb}>10 \mathrm{gr} /$ dL tidak memberikan keuntungan jangka panjang pada luaran neurologik bahkan kejadian efek samping tranfusi cenderung lebih besar. ${ }^{9}$

Terdapat hubungan yang bermakna secara statistik antara kadar $\mathrm{Hb}$ pascabedah dengan jumlah perdarahan dan tranfusi yang diberikan $(\mathrm{p}<0,05)$. Diantara jumlah perdarahan dan tranfusi, yang paling berhubungan dengan kadar $\mathrm{Hb}$ pascabedah adalah jumlah perdarahan. Dari penelitian ini 
didapatkan pasien yang mendapat tranfusi dengan $\mathrm{Hb}$ pascabedah $>10 \mathrm{gr} / \mathrm{dL}$ berjumlah 40 pasien $(71,42 \%)$. Hal ini menunjukkan bahwa pemberian transfusi pada operasi tumor otak di RS Dr. Hasan Sadikin masih berlebihan. Transfusi yang berlebihan mungkin juga dapat disebabkan karena sebagian besar permintaan transfusi di Rumah Sakit Hasan Sadikin bukan dengan jumlah tetapi dengan unit/labu. Sebab lainnya bisa karena residen/PPDS anestesi terlalu cepat dalam memulai transfusi karena dari data didapatkan bahwa pada kelompok $\mathrm{Hb}$ pascabedah $>10 \mathrm{gr} / \mathrm{dL}$, kadar Ht rata-rata saat transfusi pertama kali intrabedah yaitu pada $\mathrm{Ht}$ $29,65 \pm 4,907 \%$ ( $\mathrm{Hb} 9,36 \pm 1,71 \mathrm{gr} / \mathrm{dL})$.

Beberapa literatur memberikan saran kapan kita harus melakukan transfusi. Transfusi dapat dilakukan pada pasien dengan $\mathrm{Ht}$ normal bila kehilangan darah telah mencapai $10-20 \%$ dari estimated blood volume (EBV) atau transfusi saat $\mathrm{Ht} 24 \% .^{10}$ Literatur lain menyebutkan bahwa transfusi diberikaan saat perdarahan telah mencapai dua liter dan perdarahan masih berlangsung. ${ }^{15}$ Penelitian lain di Spanyol menyarankan agar dilakukan transfusi pada kadar $\mathrm{Hb}<7$ dan pada kadar $\mathrm{Hb} 7-10$ gr/dL bila $\mathrm{PbtO}_{2}<20 \mathrm{mmHg}$ atau $\mathrm{rSO}_{2}<60 \%$ atau terdapat penurunan fungsi kardiopulmonal. ${ }^{16}$ Sedangkan penelitian di Belgia menyimpulkan bahwa transfusi PRC dapat diberikan pada pasien dengan anemia $(\mathrm{Hb}<9-10 \mathrm{gr} / \mathrm{dL})$ yang disertai hipoksia jaringan $\left(\mathrm{PbtO}_{2}<15-20 \mathrm{mmHg}, \mathrm{SvjO}_{2}\right.$ $<55 \%) .{ }^{17}$

Sinyal transfusi untuk pasien neurocritical yang berdasar pada kadar $\mathrm{Hb}$ kurang tepat karena dapat mengakibatkan transfusi darah yang kurang dari seharusnya atau malah berlebihan. Lebih fisiologis bila sinyal transfusi datang langsung dari otak menggunakan metode invasif seperti probe intrakranial yang langsung mengukur $\mathrm{PbtO}_{2}$, dan metode noninvasif seperti spektroskopi inframerah yang secara tidak langsung mengukur saturasi oksigen serebral $\left(\mathrm{rSO}_{2}\right) \cdot{ }^{16}$ Namun karena di RS Dr. Hasan Sadikin tidak rutin menggunakan metode invasif ini, maka sinyal transfusi berdasar pada kadar $\mathrm{Hb}$ atau $\mathrm{Ht}$ yang didapat menggunakan perhitungan manual.

\section{Simpulan}

Gambaran kadar hemoglobin dan hematokrit prabedah adalah rata-rata sebesar 13,23 $\pm 1,35$ gr/dL dan 39,19 $\pm 3,54 \%$. Kadar $\mathrm{Hb}$ pascabedah didapatkan $\mathrm{Hb}<9$ gr/dL sebanyak lima belas pasien, $\mathrm{Hb}$ 9-10 gr/dL sebanyak enam pasien dan $\mathrm{Hb}>10 \mathrm{gr} / \mathrm{dL}$ sebanyak 105 pasien. Gambaran Ht pascabedah rata-rata sebesar $34,03 \pm 6,03 \%$. Jumlah perdarahan rata-rata sebesar $1159 \pm 1032,66 \mathrm{cc}$. Jumlah transfusi yang diterima tiap pasien adalah PRC ratarata sebesar $365,81 \pm 258,70 \mathrm{cc}$, FFP rata-rata sebesar 425,45 $\pm 274,78 \mathrm{cc}$ dan WB 250cc. Jumlah perdarahan berhubungan dengan jenis tumor dan jenis operasi. Kadar $\mathrm{Hb}$ pascabedah lebih ditentukan oleh jumlah perdarahan daripada pemberian transfusi. Pemberian transfusi pada pasien yang menjalani operasi tumor otak di RS Dr. Hasan Sadikin masih berlebihan.

\section{Daftar Pustaka}

1. Crawford-Sykes A, Ehikhametalor K, Tennant I, Scarlett M, Augier R, Williamson L, Wharfe G, dkk. Blood use in neurosurgical cases at the University Hospital of the West Indies. West Indian Med J.2014;63(1):54-8.

2. Ali Z, Hassan N, Syed S. Blood transfusion practices in neuroanaesthesia. Indian $\mathrm{J}$ Anaesth.2014;58:622-8.

3. Bhatnagar S, Udaya IB, Rao U. An audit of blood transfusion in elective neurosurgery. Indian J Anaesth.2007;51(3):200-4.

4. Diringer MN. Hyperoxia: good or bad for the injured brain?. Curr Opinion Crit Care.2008;14:167-71.

5. Dries DJ, Paul S. Fundamental critical care support. Edisi ke-5. Minnesota: Society of critical care medicine; 2012.

6. Kansagra AJ, Stefan MS. Preoperative anemia: evaluation and treatment. Anesthesiol Clin.2016;34:127-41. 
7. Alan N, Seicean A, Seicean S, Neuhauser $\mathrm{D}$, Weil RJ. Impact of preoperative anemia on outcomes in patients undergoing elective cranial surgery. $\mathrm{J}$ Neurosurg.2014;120:764-72.

8. Bisri DY, Bisri T. Ambang hemoglobin pada cedera otak traumatik. JNI 2016;5(3):210 17.

9. Robertson CS, Hannay J, Yamal JM, Gopinath S, Goodman JC, Tilley BC. The EPO severe TBI trial investigators. Effect of erythropoietin and transfusion threshold on neurological recovery after traumatic brain injury: a randomized clinical trial. JAMA. 2014;312(1):36-47.

10. Butterworth JF, Mackey DC, Wasnick JD. Fluid management and blood component therapy. Dalam: Morgan and Mikhail's Clinical Anesthesiology. Edisi ke-5. United state: McGraw-Hill; 2013, 1161-81.

11. Kramer AH, Zygun DA. Anemia and red blood cell transfusion in neurocritical care. Crit Care.2009;13:R89.

12. Naqash IA, Draboo MA, Lone AQ, Nengroo SH, Kirmani A, Bhat AR. Evaluation of acute normovolemic hemodilution and autotransfusion in neurosurgical patients underdoing excision of intracranial meningioma. J Anaesth Clin Pharmacol.2011;27(1):54-8.

13. Seicean A, Alan N, Seicean S, Neuhauser D, Selman WR, Bambakidis NC. Risks associated with preoperative anemia and perioperative blood transfusion in open surgery for intracranial aneurysms. J Neurosurg. 2015;123:91-100.
14. Linsler S, Ketter R, Eichler H, Karsten S, Steudel W, Oertel J. Red blood cell transfusion in neurosurgery. 2012;154:1303-8.

15. Bisri YB, Bisri T. Anestesi untuk operasi tumor otak supratentorial infratentorial. Edisi Pertama. Bandung: Fakultas Kedokteran Universitas Padjadjaran; 2016.

16. Leal-Noval SR, Gomez M, Murillo-Cabezas F. Optimal hemoglobin concentration in patients with subarachnoid hemorrhage, acute ischemic stroke and traumatic brain injury. Curr Opinion Crit Care.2008;14:15662.

17. Lelubre C, Bouzat P, Crippa IA, Taccone FS. Anemia management after acute brain injury. Crit Care.2016;20(152):1-11.

18. Griesdale DE, Sekhon MS, Menon DK, Lavinio A, Donnelly J, Robba C, Sekhon IS. Hemoglobin area and time index above $90 \mathrm{~g} / \mathrm{L}$ are associated with improved 6-month functional outcomes in patients with severe traumatic brain Injury. Neurocrit Care.2015;23:78-84.

19. Oddo M, Milby A, Chen I, Frangos S, MacMurtrie E, Maloney-Wilensky E, Stiefel M, dkk. Hemoglobin concentration and cerebral metabolism in patients with aneurysmal subarachnoid hemorrhage. Stroke. 2009;40:1275-81.

20. Sekhon MS, McLean N, Henderson WR, Chittock DR, Griesdale D. Association of hemoglobin concentration and mortality in critically ill patients with severe traumatic brain injury. Crit Care.2012;16:R.128 